\title{
Cooccurrence of Talon's Cusp with Dens Invaginatus in the Maxillary Lateral Incisor: A Case Report with Review of Literature
}

\author{
Snehashish Ghosh $\mathbb{D}^{1},{ }^{1}$ Safal Dhungel ${ }^{D},{ }^{2}$ Bhawana Subedi, ${ }^{3}$ and Subi Pradhan ${ }^{4}$ \\ ${ }^{1}$ Department of Oral Pathology, College of Medical Sciences, Bharatpur, Nepal \\ ${ }^{2}$ Department of Oral and Maxillofacial Surgery, College of Medical Sciences, Bharatpur, Nepal \\ ${ }^{3}$ Department of Oral Medicine and Radiology, College of Medical Sciences, Bharatpur, Nepal \\ ${ }^{4}$ College of Medical Sciences, Bharatpur, Nepal \\ Correspondence should be addressed to Snehashish Ghosh; drsnehashishop@gmail.com
}

Received 30 November 2021; Accepted 11 February 2022; Published 22 February 2022

Academic Editor: Sreekanth Kumar Mallineni

Copyright (c) 2022 Snehashish Ghosh et al. This is an open access article distributed under the Creative Commons Attribution License, which permits unrestricted use, distribution, and reproduction in any medium, provided the original work is properly cited.

\begin{abstract}
Morphogenic developmental anomalies are common in maxillary lateral incisors, but simultaneous occurrence of two developmental anomalies in a single tooth is relatively uncommon. In this case report, we present a case of cooccurrence of the talon's cusp with dens invaginatus in the left lateral incisor tooth. Early diagnosis and prompt treatment of such cases are important to prevent any untoward consequences.
\end{abstract}

\section{Introduction}

Talon's cusp is an additional entity, projecting from the lingual surface/cingulum area of a maxillary or mandibular anterior tooth. It is an anomalous structure resembling an eagle's talon, so the name talon's cusp has evolved. It is composed of coronal hard and soft tissue structures similar to a normal tooth. It blends smoothly with the tooth except there is a deep developmental groove where the cusp blends with the sloping lingual tooth surface [1]. The first case of the talon's cusp was identified by Mitchell [2].

Sicher and Bhaskar [3] proposed that a disturbance in the morphodifferentiation could lead to the development of the talon's cusp, whereas Hattab et al. [4] thought that the talon's cusp might be a result of outward folding of the inner enamel epithelium with concurrent focal hyperplasia of the dental papilla. It could be one of the presenting features of Mohr syndrome, Rubinstein-Taybi syndrome, and Sturge-Weber syndrome [5-8]. Some authors consider talon's cusp as a hamartoma also [9].

Various clinical problems like attrition, compromised aesthetics, displacement of the involved tooth, interference of tongue space, increased susceptibility to dental caries, and occlusal disharmony could be associated with the talon's cusp $[10,11]$.

Dens invaginatus/dens in dente is a developmental anomaly that arises as a result of infolding in the surface of the crown/root. Increased localized external pressure, focal growth retardation, and focal growth stimulation in certain areas of the tooth bud are the possible causes of this condition. Siraci et al. and Lwin et al. contemplated an initial contortion followed by the subsequent protrusion of the fragment of the enamel organ could lead to the formation of enamel-lined infolding at the cingulum area even at the incisal tip $[10,12]$.

It is seen in the order in maxillary lateral incisors, central incisors, canine, premolar, and molar teeth. Usually, it is unilateral, but when occurring in the maxillary central, it could be bilateral [12]. An analogous form of invagination occasionally occurs in the roots of teeth [10]. It results from an infolding of Hertwig epithelial root sheath and takes its origin within the root after development is complete. There is no gender predilection for this condition $[12,13]$.

Radiographically, the involved tooth may depict an infolding of enamel and dentin reaching towards the pulp cavity or even rarely extending to the root apex. 
Histopathologically, hypomineralized enamel is noted at the site of invagination, making that site vulnerable for the development of dental caries and penetration of microorganisms deep into the pulpal area leading to pulpal necrosis and initiation of periapical inflammatory processes $[10,12,14]$.

Here in this article, we report a rare case of cooccurrence of the talon's cusp with dens invaginatus in the maxillary lateral incisor.

\section{Case Report}

A 25-year-old female patient reported to the dental outpatient department of the College of Medical Sciences, Bharatpur, Nepal, with the chief complaint of the fractured tooth in the upper tooth region since 9 yrs. On extraoral examination, the patient had a prognathic mandible with an asymmetric smile, and the midline was shifted towards the right by $2 \mathrm{~mm}$.

Intraoral examination revealed the patient was in the permanent dentition stage with occlusal caries in the upper right back posterior region. She had a class I occlusal relationship. The full mouth intraoral picture is presented (Figure 1). A prominent tubercle in the lingual aspect of the upper left lateral incisor extends from the cingulum area to the incisal edge (Figure 2). This was diagnosed as a talon's cusp. The tooth was discolored, and a crack line was present on the palatal aspect. The patient did not have any problems regarding speech, mastication, and occlusion. The tooth responded well during the cold test and electric pulp test. On both horizontal and vertical percussion, the involved tooth did not show any pain.

On radiographic evaluation, a shallow $\mathrm{V}$-shaped, tapered radio-opaque structure extending from the cervical third of the crown was noted. A dens invaginatus extending apically beyond the cementoenamel junction was also noted in the same tooth (Figure 3). The apical closure of the tooth was completed. No sign of periapical pathology was witnessed.

According to clinical and radiographic findings, the case was confirmed to be type II talon's cusp together with type I dens invaginatus. As the anomaly enhances plaque accumulation and makes the tooth vulnerable to dental caries, it was advised to fill the developmental groove with sealant for preventive purposes.

As the condition was asymptomatic, the patient did not want to get any treatment done for the involved tooth. The patient was advised to follow the routine brushing practice and maintain optimum oral hygiene and seek regular dental checkups. The written consent was taken from the patient for the publication of the clinical photographs and the X-ray record.

\section{Discussion}

Anomalies like talon's cusp, dens invaginatus, and palatogingival groove are fairly seen in lateral incisor, although the exact cause for this remains unknown [15-17]. However, the simultaneous occurrence of two or more anomalies in a single tooth is relatively rare, and here, in

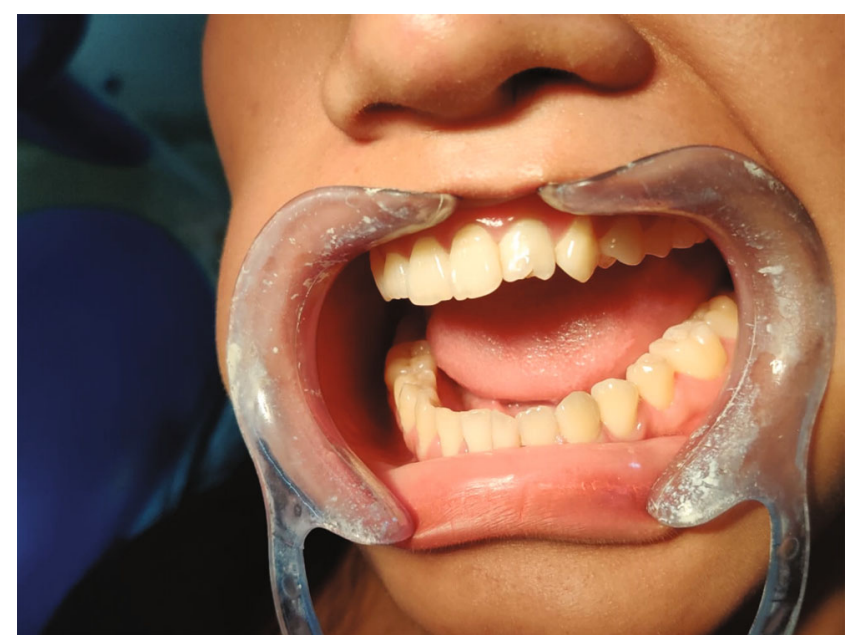

FIGURE 1: Full mouth intraoral image of the patient.

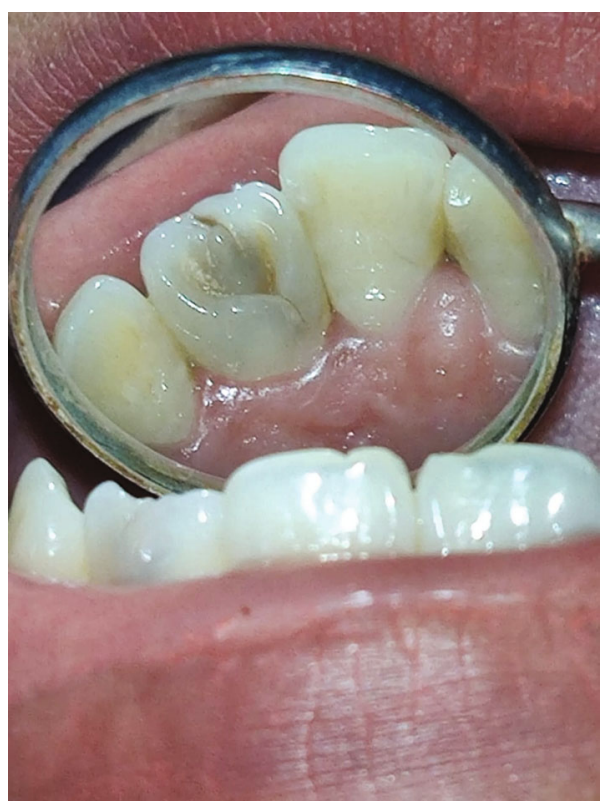

FIgURE 2: Clinical picture showing talon's cusp with dens invaginatus in maxillary left lateral incisor.

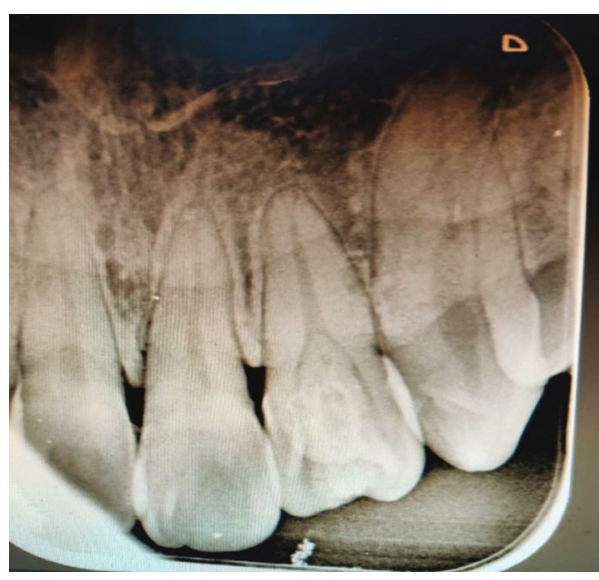

FIGURE 3: Intraoral periapical radiograph showing talon's cusp with dens invaginatus in maxillary left lateral incisor. 
TABLE 1: Classification of talon's cusp proposed by Hattab et al. [4].

\begin{tabular}{|c|c|}
\hline Types & Description \\
\hline Type I & $\begin{array}{l}\text { True talon-distinctive additional cusp projecting from the lingual/cingulum surface of maxillary/mandibular } \\
\text { anterior teeth to at least half a distance from the amelocemental junction to the incisal edge }\end{array}$ \\
\hline Type II & $\begin{array}{l}\text { Semitalon-an additional cusp of } 1 \mathrm{~mm} \text { or more that extends less than half of the distance from the } \\
\text { amelocemental junction to the incisal edge, and it blends well with the lingual surface of the teeth. }\end{array}$ \\
\hline Type III & Trace talon-prominence/variation in the cingulum, could be conical, bifid, or tubercle-like \\
\hline
\end{tabular}

TABLe 2: Classification of dens invaginatus proposed by Oehlers et al. [24].

\begin{tabular}{lr}
\hline Types & Description \\
\hline $\begin{array}{l}\text { Type I } \\
\text { Type II }\end{array}$ & Invagination is restricted to the crown up to the cementoenamel junction. \\
Type IIIa & Invagination extends into the root beyond the cementoenamel junction. \\
Type IIIb & Invagination extends into the tooth with lateral communication to the periodontal ligament. \\
\hline
\end{tabular}

TABLE 3: Summary of the reported cases of talon's cusp/dens evaginatus with dens invaginatus documented till date.

\begin{tabular}{|c|c|c|c|c|c|c|}
\hline $\begin{array}{l}\text { Serial } \\
\text { No. }\end{array}$ & Author/year & Sex & $\begin{array}{l}\text { Primary } \\
\text { anomaly }\end{array}$ & Tooth involved & $\begin{array}{c}\text { Associated } \\
\text { anomaly }\end{array}$ & Treatment performed \\
\hline 01 & $\begin{array}{c}\text { Lorena et al./ } \\
2003 \text { [27] }\end{array}$ & Male & $\begin{array}{l}\text { Talon's } \\
\text { cusp }\end{array}$ & $\begin{array}{l}\text { Maxillary left lateral } \\
\text { incisor }\end{array}$ & $\begin{array}{c}\text { Dens } \\
\text { invaginatus }\end{array}$ & No treatment \\
\hline 02 & $\begin{array}{l}\text { Tiku et al./ } \\
2004[18]\end{array}$ & Female & $\begin{array}{l}\text { Talon's } \\
\text { cusp }\end{array}$ & $\begin{array}{l}\text { Maxillary left lateral } \\
\text { incisor }\end{array}$ & $\begin{array}{c}\text { Dens } \\
\text { invaginatus }\end{array}$ & No treatment \\
\hline 03 & $\begin{array}{c}\text { Mupparapu } \\
\text { et al./2004 [28] }\end{array}$ & Male & $\begin{array}{c}\text { Dens } \\
\text { evaginatus }\end{array}$ & $\begin{array}{l}\text { Maxillary right lateral } \\
\text { incisor }\end{array}$ & $\begin{array}{c}\text { Dens } \\
\text { invaginatus }\end{array}$ & $\begin{array}{c}\text { Prophylactic treatment with glass ionomer } \\
\text { cement }\end{array}$ \\
\hline 04 & $\begin{array}{l}\text { Siraci et al./ } \\
2008[10]\end{array}$ & Female & $\begin{array}{l}\text { Talon's } \\
\text { cusp }\end{array}$ & $\begin{array}{l}\text { Mandibular right central } \\
\text { incisor }\end{array}$ & $\begin{array}{c}\text { Dens } \\
\text { invaginatus }\end{array}$ & $\begin{array}{l}\text { Grinding followed by prophylactic sealing } \\
\text { with flowable composite }\end{array}$ \\
\hline 05 & $\begin{array}{l}\text { Anthonappa } \\
\text { et al./2008 [29] }\end{array}$ & Female & $\begin{array}{c}\text { Dens } \\
\text { evaginatus }\end{array}$ & $\begin{array}{l}\text { Maxillary right lateral } \\
\text { incisor }\end{array}$ & $\begin{array}{c}\text { Dens } \\
\text { invaginatus }\end{array}$ & $\begin{array}{c}\text { Prophylactic treatment with glass ionomer } \\
\text { cement }\end{array}$ \\
\hline 06 & $\begin{array}{c}\text { Vardhan et al./ } \\
2010[30]\end{array}$ & Male & $\begin{array}{l}\text { Talon's } \\
\text { cusp }\end{array}$ & $\begin{array}{l}\text { Maxillary right and left } \\
\text { central and lateral incisor }\end{array}$ & $\begin{array}{c}\text { Dens } \\
\text { invaginatus }\end{array}$ & No treatment \\
\hline 07 & $\begin{array}{l}\text { Sarraf-Shirazi } \\
\text { et al./2010 [31] }\end{array}$ & Male & $\begin{array}{l}\text { Talon's } \\
\text { cusp }\end{array}$ & $\begin{array}{l}\text { Maxillary right and left } \\
\text { central incisor }\end{array}$ & $\begin{array}{c}\text { Dens } \\
\text { invaginatus }\end{array}$ & Endodontic treatment \\
\hline 08 & $\begin{array}{c}\text { Yadav et al./ } \\
2011[15]\end{array}$ & & $\begin{array}{l}\text { Talon's } \\
\text { cusp }\end{array}$ & $\begin{array}{l}\text { Maxillary left lateral } \\
\text { incisor }\end{array}$ & $\begin{array}{c}\text { Dens } \\
\text { invaginatus }\end{array}$ & $\begin{array}{c}\text { Enameloplasty with prophylactic composite } \\
\text { resin treatment }\end{array}$ \\
\hline 09 & $\begin{array}{c}\text { Nagaveni } \\
\text { et al./2011 [32] }\end{array}$ & Male & $\begin{array}{l}\text { Talon's } \\
\text { cusp }\end{array}$ & $\begin{array}{l}\text { Mandibular left central } \\
\text { incisor }\end{array}$ & $\begin{array}{c}\text { Dens } \\
\text { invaginatus }\end{array}$ & $\begin{array}{c}\text { Prophylactic treatment with glass ionomer } \\
\text { cement }\end{array}$ \\
\hline 10 & $\begin{array}{c}\text { Akers et al./ } \\
2014[33]\end{array}$ & Male & $\begin{array}{c}\text { Dens } \\
\text { invaginatus }\end{array}$ & $\begin{array}{l}\text { Maxillary left lateral } \\
\text { incisor }\end{array}$ & Dens evaginatus & Endodontic treatment \\
\hline 11 & $\begin{array}{c}\text { Kasat et al./ } \\
2014[34]\end{array}$ & Female & $\begin{array}{l}\text { Talon's } \\
\text { cusp }\end{array}$ & $\begin{array}{l}\text { Maxillary left lateral } \\
\text { incisor }\end{array}$ & $\begin{array}{c}\text { Dens } \\
\text { invaginatus, } \\
\text { radicular cyst }\end{array}$ & $\begin{array}{l}\text { Endodontic treatment of the teeth with } \\
\text { enucleation of the cyst }\end{array}$ \\
\hline 12 & $\begin{array}{c}\text { Babaji /2015 } \\
{[35]}\end{array}$ & Male & $\begin{array}{c}\text { Dens } \\
\text { invaginatus }\end{array}$ & $\begin{array}{l}\text { Supplemental maxillary } \\
\text { left central incisor }\end{array}$ & Dens evaginatus & $\begin{array}{c}\text { Extraction as both talon's cusp and dens } \\
\text { invaginatus were there on supplemental tooth }\end{array}$ \\
\hline 13 & $\begin{array}{l}\text { Lwin et al./ } \\
2017[12]\end{array}$ & Male & $\begin{array}{l}\text { Talon's } \\
\text { cusp }\end{array}$ & $\begin{array}{l}\text { Maxillary right lateral } \\
\text { incisor }\end{array}$ & $\begin{array}{l}\text { Double dens } \\
\text { invaginatus }\end{array}$ & Restoration with pit and fissure sealant \\
\hline 14 & Present case & Female & $\begin{array}{l}\text { Talon's } \\
\text { cusp }\end{array}$ & $\begin{array}{l}\text { Maxillary left lateral } \\
\text { incisor }\end{array}$ & Dens evaginatus & No treatment \\
\hline
\end{tabular}

this case, we reported the concurrent occurrence of a talon's cusp with dens invaginatus in the maxillary left lateral incisor of the same patient. Talon's cusp reported, in this case, is a "semitalon," according to the classification proposed by Hattab et al. [4], which is mentioned in Table 1. 
Studies have shown that the prevalence of talon's cusp varies in different ethnic groups ranging from $0.06 \%$ in Mexican children to about $7.7 \%$ in Indian children. Mongolians show a higher incidence rate of talon's cusp when compared with Caucasians and Negroes [15-18]. Talon's cusp can occur concurrently with other anomalies like bifid cingulum, dens invaginatus, impacted mesiodens, macrodontia, odontoma, and supernumerary tooth $[15,19-21]$. These anomalies can alter the vitality of the pulp and can remain asymptomatic $[10,15]$ as well and get diagnosed under routine radiographic examination $[10,12,15]$ which happened in the present case.

Dens invaginatus carries a significantly increased risk of developing into a pulpal pathology. The invaginated portion communicates with the oral cavity, facilitating the ingress of irritants and microbes into the pulp causing pulpal and periapical pathosis $[15,22]$. Its incidence is 0.04 to $10 \%$ and is usually detected on a routine roentogenic evaluation [23]. As these pathologies are developmental, the apical rootend closure is questionable if there is pulpal involvement in such a tooth with an open apex [15]. Dens invaginatus reported in this case belongs to the type II variant as per Oehlers classification of dens invaginatus [24], which is mentioned in Table 2. Dens invaginatus might coexist with other developmental anomalies like double teeth, shoveling of the incisor, and multirooted anterior teeth $[15,16,25$, 26]. The documented cases, presenting with the cooccurrence of talon's cusp with dens invaginatus, are summarized in Table 3.

The treatment approach varies from case to case. An asymptomatic talon's cusp without any occlusal interference is left untreated, and vigorous oral hygiene and routine monitoring are good enough, whereas any interference with speech and occlusion requires reduction of the cusp with the application of a desensitizing agent; sometimes intentional endodontic treatment and coverage by full-thickness crown may be required to prevent dental caries and premature tooth loss. The management of dens invaginatus may range from simple oral hygiene instructions, frequent monitoring, and conservative restoration to endodontic treatment, which depends exclusively on the presenting symptoms $[10,12,15]$.

The clinical significance of talon's cusp and dens invaginatus is they could be associated with compromised function and esthetics, and as they serve an attachment area for the attachment of food particles, dental plaque, they have a high chance to get affected by the carious process $[12,15]$. The message to the clinicians through this case report is that whenever such a case is encountered, early diagnosis and prompt treatment should be performed to restore the function, improve the prognosis, minimize potential complications, and improve the quality of life of the patient.

Based on the research data, both talon's cusp and dens invaginatus are seen unilaterally on the lateral incisors [12]. Although both of these developmental anomalies are not uncommon, based on the knowledge of the authors, the concurrent occurrence of talon's cusp with dens invaginatus in a single tooth has not been reported in the Nepalese population till date.

\section{Conclusion}

To summarize, talon's cusp and dens invaginatus are the developmental anomalies noted in the anterior teeth. They could be asymptomatic or could be associated with the symptoms mentioned in this case report. Its early detection and prompt intervention can alleviate the symptoms in symptomatic cases, prevent premature tooth loss, enhance esthetics, and overall improve the well-being of the patient.

\section{Data Availability}

The figures/data have already been made available in the manuscript.

\section{Consent}

Written informed consent was obtained from the patient to publish this report by the journal's patient consent policy.

\section{Conflicts of Interest}

The authors declare that they have no conflicts of interest.

\section{References}

[1] R. Rajendran, Shafer's Textbook of Oral Pathology, Elsevier, India, 2009.

[2] W. H. Mitchell, “Case report," Dental Cosmos, vol. 36, 1892.

[3] S. Sicher and S. N. Bhaskar, Orban's Oral Histology and Embryology, CV Mosby Company, St Louis, Mo, 7th ed. edition, 1972.

[4] F. N. Hattab, O. M. Yassin, and K. S. Al-Nimri, "Talon cuspclinical significance and management: case reports," Quintessence International, vol. 26, no. 2, pp. 115-120, 1995.

[5] D. G. Gardner and S. S. Girgis, "Talon cusps: a dental anomaly in the Rubinstein-Taybi syndrome," Oral Surgery, Oral Medicine, and Oral Pathology, vol. 47, no. 6, pp. 519-521, 1979.

[6] E. Goldstein and J. L. Medina, "Mohr syndrome or oralfacialdigital II: report of two cases," Journal of the American Dental Association, vol. 89, no. 2, pp. 377-382, 1974.

[7] R. J. Chen and H. S. Chen, "Talon cusp in primary dentition," Oral Surgery, Oral Medicine, and Oral Pathology, vol. 62, no. 1, pp. 67-72, 1986.

[8] T. Tsutsumi and H. Oguchi, "Labial talon cusp in a child with incontinentia pigmenti achromians: case report," Pediatric Dentistry, vol. 13, pp. 236-237, 1991.

[9] S. Patil, R. S. Rao, and B. Majumdar, "Hamartomas of the oral cavity," Journal of International Society of Preventive \& Community Dentistry, vol. 5, no. 5, pp. 347-353, 2015.

[10] E. Siraci, H. C. Gungor, and Z. C. Cehreli, "Dens invaginatus and talon cusp co-occurring in a mandibular central incisor: a case report," Journal of Dentistry for Children, vol. 75, no. 2, pp. 177-180, 2008.

[11] C. L. Mader, "Talon cusp," Journal of the American Dental Association, vol. 103, no. 2, pp. 244-246, 1981.

[12] H. N. Lwin, P. P. Kyaw, and S. W. Thu, "Coexistence of true talon cusp and double dens invaginatus in a single tooth: a rare case report and review of the literature," Clinical Case Reports, vol. 5, no. 12, pp. 2017-2021, 2017. 
[13] B. W. Neville, D. D. Damm, A. C. Chi, and C. M. Allen, Oral and Maxillofacial Pathology, Elsevier, St. Louis, MO, 2015.

[14] M. Hülsmann, "Dens invaginatus: aetiology, classification, prevalence, diagnosis, and treatment considerations," International Endodontic Journal, vol. 30, no. 2, pp. 79-90, 1997.

[15] M. Yadav, S. M. Meghana, and S. R. Kulkarni, "Concommitant occurance of dens invaginatus and talon cusp: a case report," Revista Odonto Ciência, vol. 26, no. 2, pp. 187-190, 2011.

[16] J. J. Segura and A. Jiménez-Rubio, "Talon cusp affecting permanent maxillary lateral incisors in 2 family members," Oral Surgery, Oral Medicine, Oral Pathology, Oral Radiology, and Endodontics, vol. 88, no. 1, pp. 90-92, 1999.

[17] E. A. O'Sullivan, "Multiple dental anomalies in a young patient: a case report," International Journal of Paediatric Dentistry, vol. 10, no. 1, pp. 63-66, 2000.

[18] A. Tiku, U. M. Nadkarni, and S. G. Damle, "Management of two unusual cases of dens invaginatus and talon cusp associated with other dental anomalies," Journal of the Indian Society of Pedodontics and Preventive Dentistry, vol. 22, no. 3, pp. 128133, 2004.

[19] P. J. Davis and A. H. Brook, "The presentation of talon cusp: diagnosis, clinical features, associations and possible aetiology," British Dental Journal, vol. 160, pp. 84-88, 1985.

[20] E. Natkin, D. L. Pitts, and P. Worthington, "A case of talon cusp associated with other odontogenic abnormalities," Journal of Endodontia, vol. 9, no. 11, pp. 491-495, 1983.

[21] S. K. Mallineni, G. K. Panampally, Y. Chen, and T. Tian, "Mandibular talon cusps: a systematic review and data analysis," Journal of Clinical and Experimental Dentistry, vol. 6, no. 4, 2014.

[22] S. C. White and M. J. Pharoah, Dental Anomalies. Oral Radiology: Principles and Interpretation, Mosby, New York, NY, USA, 5th ed. edition, 2004.

[23] P. V. Abbot, "Labial and palatal "talon cusp" on the same tooth-a case report," Oral Surgery, Oral Medicine, Oral Pathology, Oral Radiology, and Endodontics, vol. 85, no. 6, pp. 726730, 1998.

[24] F. A. Oehlers and Dens invaginatus. II., "Associated posterior crown forms and pathogenesis," Oral Surgery, Oral Medicine, and Oral Pathology, vol. 10, no. 12, pp. 1302-1316, 1957.

[25] M. Gul, S. Adnan, and F. Umer, "A variant of the current dens invaginatus classification," Frontiers in Dentistry, vol. 17, p. 28 , 2020.

[26] M. Ekambaram, C. K. Yiu, and N. M. King, "An unusual case of double teeth with facial and lingual talon cusps," Oral Surgery, Oral Medicine, Oral Pathology, Oral Radiology, and Endodontology, vol. 105, no. 4, pp. e63-e67, 2008.

[27] S. C. Lorena, D. T. Oliveira, and E. W. Odellt, "Multiple dental anomalies in the maxillary incisor region," Journal of Oral Science, vol. 45, no. 1, pp. 47-50, 2003.

[28] M. Mupparapu, S. R. Singer, and J. H. Goodchild, "Dens evaginatus and dens invaginatus in a maxillary lateral incisor: report of a rare occurrence and review of literature," Australian Dental Journal, vol. 49, no. 4, pp. 201-203, 2004.

[29] R. Anthonappa, C. Yiu, and N. King, "A novel combination of dens evaginatus and dens invaginatus in a single tooth-review of the literature and a case report," Journal of Clinical Pediatric Dentistry, vol. 32, no. 3, pp. 239-242, 2008.

[30] T. H. Vardhan and S. Shanmugam, "Dens evaginatus and dens invaginatus in all maxillary incisors: report of a case," Quintessence International, vol. 41, no. 2, pp. 105-107, 2010.
[31] A. Sarraf-Shirazi, M. Rezaiefar, and M. Forghani, "A rare case of multiple talon cusps in three siblings," Brazilian Dental Journal, vol. 21, no. 5, pp. 463-466, 2010.

[32] N. B. Nagaveni, K. V. Umashanikara, B. G. Vidyullatha, S. Sreedevi, and N. B. Radhika, "Permanent mandibular incisor with multiple anomalies - report of a rare clinical case," Brazilian Dental Journal, vol. 22, no. 4, pp. 346-350, 2011.

[33] H. F. Akers, C. M. Henderson, and M. A. Foley, "Diagnosis and management of a maxillary lateral incisor exhibiting dens invaginatus and dens evaginatus," Australian Endodontic Journal, vol. 40, no. 1, pp. 32-38, 2014.

[34] V. O. Kasat, M. Singh, H. Saluja, and R. Ladda, "Coexistence of two talon cusps and two dens invaginatus in a single tooth with associated radicular cyst-a case report and review of literature," Journal of Clinical and Experimental Dentistry, vol. 6, no. 4, 2014.

[35] P. Babaji, "Bilateral supplemental maxillary incisors with both dens invaginatus and dens evaginatus in a non syndromic patient: a rare case report," Journal of Clinical and Diagnostic Research: JCDR, vol. 9, no. 1, pp. ZJ01-ZJ02, 2015. 